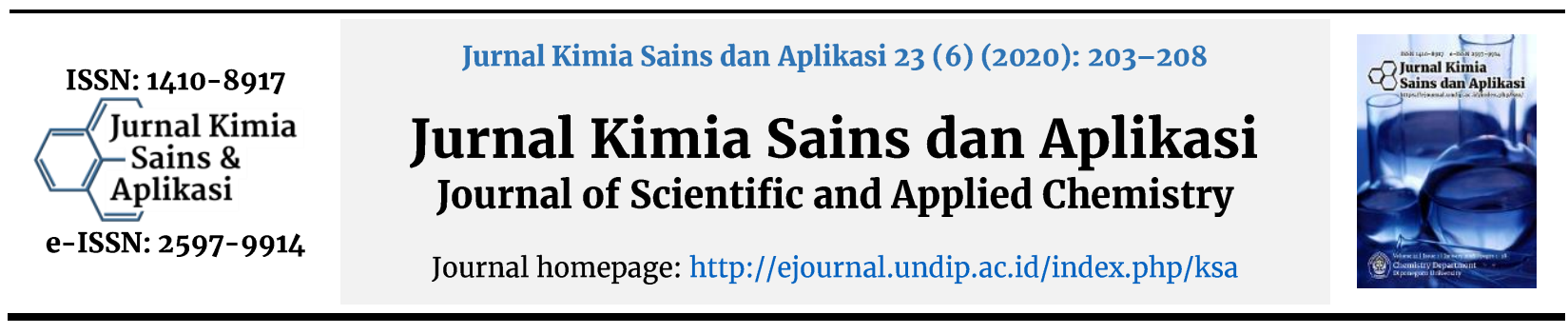

\title{
Bioplastic from Pectin of Dragon Fruit (Hylocereus polyrhizus) Peel
}

\author{
Risnita Vicky Listyarini ${ }^{\mathrm{a},{ }^{*}}$, Puspita Ratna Susilawati ${ }^{\mathrm{b}}$, Esther Natalia Nukung ${ }^{\mathrm{a}}$, \\ Maria Anastasia Toyo Yua ${ }^{a}$ \\ ${ }^{\text {a }}$ Chemistry Education Study Program, Universitas Sanata Dharma, Yogyakarta, Indonesia \\ ${ }^{\mathrm{b}}$ Biology Education Study Program, Universitas Sanata Dharma, Yogyakarta, Indonesia \\ * Corresponding author: risnita.vicky@usd.ac.id
}

https://doi.org/10.14710/jksa.23.6.203-208

\begin{tabular}{l} 
Article Info \\
\hline Article history: \\
Received: $10^{\text {th }}$ March 2020 \\
Revised: $17^{\text {th }}$ May 2020 \\
Accepted: $31^{\text {st }}$ May 2020 \\
Online: $30^{\text {th }}$ June 2020 \\
\hline
\end{tabular}

Keywords:

bioplastic; dragon fruit peel; pectin

\begin{abstract}
Plastic derived from petroleum is challenging to degrade and pollute the environment. There are alternatives to making biodegradable plastics to reduce the adverse effects of plastics on the environment. This study aims to utilize dragon fruit peel waste as a material for making bioplastic. Plastic characterization was carried out by FTIR analysis to determine the functional groups contained in bioplastics. The results showed that dragon fruit peel could be extracted by $\mathrm{HCl}$ solution, and the pectin yield is $11 \%$. Extracted pectin was used to make bioplastics with and without the addition of ethylene glycol. The results showed that moisture content of bioplastics of dragon fruit peel pectin is $5.71-12 \%$, while dragon fruit peel pectin and ethylene glycol are $2.86-5.71 \%$. FT-IR spectra showed that the bioplastics from dragon fruit peels belong to the pectin group, which produces carbonyl absorption at $1636-1628 \mathrm{~cm}^{-1}$ and stretching $\mathrm{C}-\mathrm{O}$ stretch at 1098$1101 \mathrm{~cm}^{-1}$.
\end{abstract}

\section{Introduction}

The use of plastic has become part of daily life because of the versatile function of plastics in various life sectors. However, plastic also poses a significant threat to the environment where plastic causes soil pollution because it occupies about $25 \%$ of the total volume of land on earth [1]. Plastics are made from polymer compounds derived from cracking or breaking of long chains of petroleum hydrocarbons. Usually, plastics are made of polyethylene terephthalate (PET), low and high-density polyethylene (LDPE and HDPE), polyvinyl chloride (PVC), polypropylene (PP) and polystyrene (PS) [2, 3]. The use of plastic derived from petroleum endangers the environment as these plastic products survive in the environment and are difficult to degrade, causing environmental problems [3, 4].

The negative effects of the use of plastics that have been synthesized from petroleum have led to the production of plastics that originate from the use of easily degraded materials. These materials can come from vegetables, animals, or microbial materials [5]. Bioplastics are defined as plastics that have characteristics derived from biological creatures, are biodegradable, or contain both of these characteristics $[6,7]$. Starch-containing plants can be used as ingredients to make bioplastics [8]. These plants include corn, potatoes, wheat, tapioca, and rice, in which the most widely used material in making bioplastics is corn. However, challenges also arise because corn is a food commodity, resulting in competition occurs between the corn used to be a food source and a bioplastic source [5].

Food waste or agricultural waste has the potential to be used as material for bioplastics. According to the Economist Intelligence Unit, Indonesia produced food waste nearly 300 kilograms of food waste per person in 2016 [9]. Food waste is mostly organic waste from fruit and vegetable peels, expired foodstuffs, or uneaten dishes. Parts such as peel, seeds, stems, and parts that are not edible are usually discarded and no longer utilized [10]. Several papers reported the potential use of food waste, especially waste materials from fruit and vegetables, to become bioplastics. Food waste such as citrus peel and apple pomace can be used for bioplastic and biofilm production [11, 12, 13]. Citrus peel and apple pomace are by-products obtained from juice or cider production. Food waste is generated every year in the world, including Indonesia. One of the fruits which have 
high demand in Indonesia is dragon fruit. Studies show that dragon fruit contains anthocyanin and other minerals such as potassium, magnesium, calcium, and vitamin, suitable for the body $[14,15,16,17]$. The production of dragon fruit is 737.5 tons annually, with a demand of around 1475 tons [18]. It is expected that dragon fruit peel will be produced every year and can be utilized for bioplastic production.

In general, fruit peels contain polysaccharides, i.e., pectin, and cellulose, to be used as material for making biodegradable plastics. Fruit peel waste also contains pectin $[19,20]$, a complex polysaccharide compound with the main component of D-galacturonic acid. Pectin is naturally contained in ripe fruits that are often used in the pharmaceutical, cosmetic, and food fields as a counterweight, thickener, and emulsifier. Dragon fruit peel weights of $30-35 \%$ of the fruit's weight contain pectin $\pm 10.8 \%$. Dragon fruit peels have not been used maximally and are discarded as agricultural waste [21, 22]. Several studies have reported pectin extraction from dragon fruit $[15,22,23,24]$. There is also increasing interest in using pectin for biofilms for fresh vegetable coating [25]. Moreover, the utilization of food waste and agricultural waste into bioplastic products can add economic value to the material [26].

Making of bioplastics from agricultural waste is carried out to utilize waste into more useful products. This study aims to investigate the extraction of pectin and to make bioplastic from dragon fruit peel pectin.

\section{Methodology}

\subsection{Materials and Tools}

The dragon fruit peel was obtained from the traditional market in Yogyakarta. Other materials were concentrated $\mathrm{HCl}$ (Merck), ethanol (Merck), $2 \mathrm{M} \mathrm{HCl}$ solution, $2 \mathrm{M} \mathrm{NaOH}$ (Merck) solution, distilled water, pectin (CV. Chemix Pratama Yogyakarta) and ethylene glycol (CV. Chemix Pratama Yogyakarta). The tools used in the study were beaker glasses, stirring rods, spoons, hotplates, universal indicators, pipettes drop, ovens, centrifuges, filters, gauze, mortar \& pestle, blenders, stopwatches, labels, watch glass and Fourier Transform Infrared Spectrophotometer (IRSpirit-T Shimadzu) with DLATGS detector.

\subsection{Preparation of Dragon Fruit Peel}

Dragon fruit peel waste was washed and heated in an oven at $55^{\circ} \mathrm{C}$ for 48 hours. Dragon fruit peel was mixed with a blender so that the powder was produced. The powder was then filtered with a ten-mesh filter and stored in a tightly closed container.

\subsection{Pectin Extraction}

$10 \mathrm{~g}$ of dragon fruit peel powder was added with 150 $\mathrm{mL}$ of distilled water. Pectin extraction of pectin was carried out using hot dilute mineral acid at $\mathrm{pH} \sim 2$ [27]. The mixture was added with $2 \mathrm{M} \mathrm{HCl}$ to get a $\mathrm{pH}$ of 2.0. The mixture was stirred and heated at $50^{\circ} \mathrm{C}$ until it becomes a homogeneous mixture for $60 \mathrm{~min}$ [27, 28, 29]. Extraction using dilute $\mathrm{HCl}$ and heating in 60 minutes caused protopectin to hydrolyze into pectin to get more pectin precipitated. The filtrate was filtered and added with $150 \mathrm{~mL}$ of ethanol and left for 60 minutes at room temperature. The pectin was precipitated and centrifuged at $1500 \mathrm{rpm}$ for 20 minutes. The precipitated pectin was then washed with ethanol with composition 1: 2 (pectin: ethanol). The mixture was centrifuged at $1500 \mathrm{rpm}$ for $30 \mathrm{~min}$. The pectin obtained was then heated in an oven at $50^{\circ} \mathrm{C}$ for 24 hours. The dried pectin was mashed and filtered with a ten mesh filter. The pectin yield was calculated as follows.

$$
\text { Pectin yield }(\%)=\frac{\text { Extracted pectin }}{\text { Dried dragon fruit powder (g) }} \times 100 \%
$$

\subsection{Preparation of Bioplastics}

$0.23 \mathrm{~g}$ dragon fruit pectin was added with $4.5 \mathrm{~mL}$ of distilled water. The mixture was added with $1 \mathrm{M} \mathrm{NaOH}$ solution to neutral $\mathrm{pH}$. Two experiments were carried out in which mixture 1 (without plasticizer), mixture 2 (ethylene glycol $0.5 \mathrm{~mL} / \mathrm{g}$ pectin). The mixture was smeared on the glass and dried in an oven at $50^{\circ} \mathrm{C}$ for 2 hours.

\subsection{Determination of Moisture Content}

Bioplastics were weight and heated in an oven at 100 ${ }^{\circ} \mathrm{C}$ with variation time 30 minutes, 60 minutes, 120 minutes, 24 hours and 48 hours until the weight is constant $[30,31]$. The moisture content was defined as mass loss during heating and calculated as follows [11, 30, 32].

$$
\text { Moisture content }(\%)=\frac{\mathrm{W} 1(\mathrm{~g})-\mathrm{W} 2(\mathrm{~g})}{\mathrm{W} 1(\mathrm{~g})} \times 100 \%
$$

where W1 = weight of sample before heating $(\mathrm{g})$, $\mathrm{W} 2=$ weight of sample after heating $(\mathrm{g})[33,34]$.

\subsection{FT-IR Spectroscopy Analysis}

Bioplastics were analyzed by the Fourier Transform Infrared Spectrophotometer (IRSpirit-T Shimadzu) with a DLATGS detector in the Chemistry Education Study Program Laboratory of Universitas Sanata Dharma. The spectra were recorded at absorbance mode from 4000 to $400 \mathrm{~cm}^{-1}$. Also, the commercial pectin bioplastic (CV. Chemix Pratama Yogyakarta) was prepared using Method 2.4 mentioned above. Three samples of bioplastics, i.e., commercial pectin bioplastic, bioplastics of dragon fruit peel pectin, and bioplastic of dragon fruit peel pectin plus ethylene glycol, were analyzed using FT-IR spectrophotometer.

\section{Results and Discussion}

\subsection{Extraction and preparation of bioplastics}

The pectin yield was $\sim 11 \%$, and this result is not high because of the longer duration of hot water extraction influences the pectin yield [15]. This result in line with the study of [15], which obtained 16.20-20.34\% of pectin yield using an extraction duration of $20,40,60$, and $80 \mathrm{~min}$. However, the study of [15] was not used to dilute acid in extraction, which caused pectin yield to differ slightly from this study.

Bioplastics are synthesized with and without the addition of plasticizer. Ethylene glycol is a plasticizer 
used for improving the elasticity of bioplastics [6, 22]. The surface bioplastic morphologies of the dragon fruit peel pectin are presented in Figure 1. Figure 1 (a) is a bioplastic of dragon fruit peel pectin without ethylene glycol, which is rigid and difficult to be separated from the printing glass. Whereas Figure $1(b)$ is a bioplastic of dragon fruit peel pectin with ethylene glycol, which is easily separated from the printing glass.

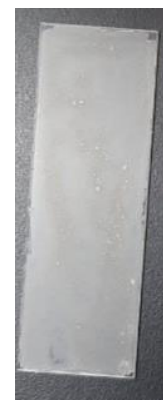

(a)

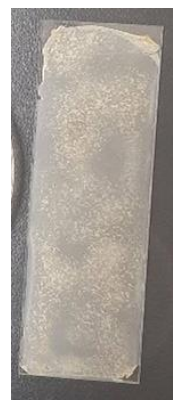

(b)
Figure 1. Bioplastics (a) of dragon fruit peel pectin; (b) dragon fruit peel pectin and ethylene glycol morphology of the surface.

Although several studies have reported pectin extraction from dragon fruit peel, the studies on bioplastic production from dragon fruit pectin are still limited [15, 22, 23, 24]. In general, plasticizers are added to improve intermolecular interactions and bioplastic properties. Ethylene glycol decreases the density of the bioplastics. The formation of hydrogen bonds in the polymer chain causes a decrease in bioplastic density. Bioplastic stiffness is reduced because ethylene glycol lowers the polymer chain [35].

\subsection{Moisture Content of Bioplastics}

Bioplastic moisture content is shown in Table 1. Moisture content in bioplastics indicates the amount of water in the bioplastic. The bioplastics show constant mass after 60 minutes of heating. The moisture content of bioplastics of dragon fruit peel pectin is $5.71-12 \%$, whereas dragon fruit peel pectin and ethylene glycol is $2.86-5.71 \%$.

Table 1. Moisture Content (\%) of bioplastic

\begin{tabular}{cc}
\hline Sample & Moisture content (\%) \\
\hline Bioplastics of dragon fruit & 5.71 \\
peel pectin & 12 \\
& 12 \\
\hline Bioplastic of dragon fruit & 2.86 \\
peel pectin and ethylene & 5.71 \\
glycol & 3.33 \\
\hline
\end{tabular}

Heating bioplastic at $100^{\circ} \mathrm{C}$ evaporates water in bioplastics. The loss of water results in bioplastic to be more rigid. Bioplastic moisture content is connected with its capability to absorb water from the surrounding environment. Moisture content depends on ambient conditions [11]. Bioplastic tends to absorb water, which can result in lower elasticity. The moisture content of bioplastic may alter the elasticity of the resulting plastic
[36]. The moisture content in bioplastic of dragon fruit peel pectin and ethylene glycol is due to ethylene glycol absorbing ambient moisture.

\subsection{FT-IR Spectroscopy}

Bioplastics are analyzed to identify the functional groups. The pectin functional group is usually present in the region between 1000 and $2000 \mathrm{~cm}^{-1}$ in the FTIR spectrum [23]. FTIR spectra of pure commercial pectin plastics, dragon fruit skin pectin bioplastics, and dragon fruit pectin bioplastics and ethylene glycol are presented in Figure 2.

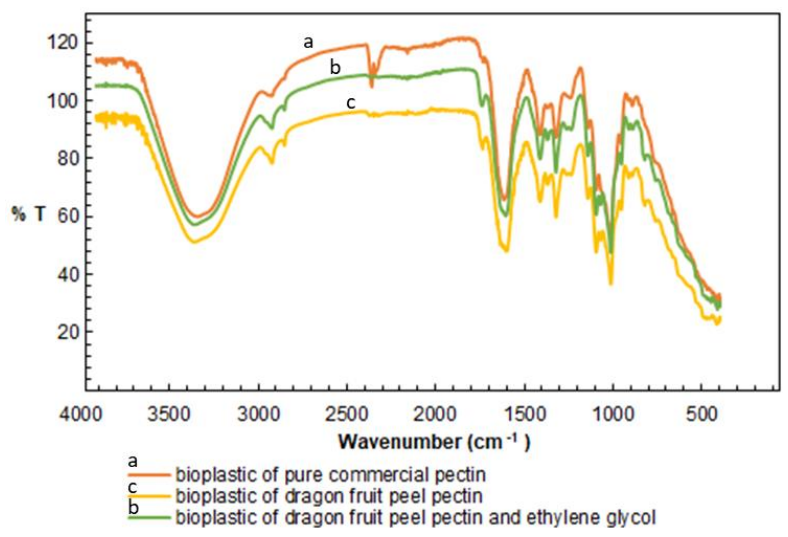

Figure 2. Bioplastics FT-IR spectra: pure commercial pectin; dragon fruit peel pectin; dragon fruit pectin and ethylene glycol

Analysis of the bioplastic functional group of dragon fruit peel pectin using FT-IR is presented in Table 2 . The presence of carbonyl groups is at $1636 \mathrm{~cm}^{-1}$ for bioplastic of dragon fruit peel (without plasticizer) and $1628 \mathrm{~cm}^{-1}$ for bioplastic of dragon fruit peel with ethylene glycol, which indicates that the sample contains pectin group. This follows with the FTIR results for pure pectin, which shows absorption at $1625-1604 \mathrm{~cm}^{-1}$. The presence of the C-O stretching group at $1098 \mathrm{~cm}^{-1}$ in bioplastic samples from dragon fruit peels (without plasticizers) and bioplastics from dragon fruit peel with ethylene glycol shows that the samples contain pectin groups. This is consistent with the results of pure pectin FT-IR, which shows adsorption at $1098 \mathrm{~cm}^{-1}$. The results of the three samples follow previous studies [22, 23, 37].

The addition of ethylene glycol in pectin bioplastics of dragon fruit increases the intensity of the carboxyl OH functional group [37, 38]. The FT-IR spectrum of dragon fruit pectin bioplastics without plasticizer or ethylene glycol has the same wavenumber as the bioplastic FT-IR spectrum for pure commercial pectin. Agustin and Padmawijaya [39] reported that the bioplastic FT-IR spectrum has the same wavenumber as the FT-IR of the bioplastic's main ingredient, namely pectin. Bioplastics' making by the addition of chemical additives (plasticizers) is through a physical mixing process [37, 39, 40]. FT-IR results show no new functional groups; in other words, there is no chemical change, which implies that bioplastic production is merely physical mixing [37]. 
Table 2. Function groups of dragon fruit peel pectin bioplastic

\begin{tabular}{|c|c|c|c|c|}
\hline \multicolumn{3}{|c|}{ Wavenumber (cm-1) } & \multirow[b]{2}{*}{$\begin{array}{c}\text { Functional } \\
\text { Group }\end{array}$} & \multirow[b]{2}{*}{ References } \\
\hline 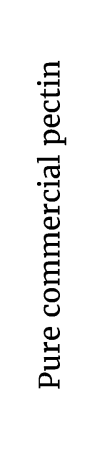 & 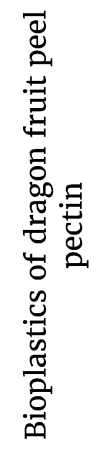 & 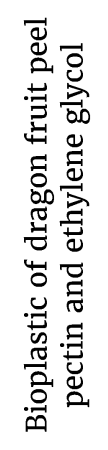 & & \\
\hline $\begin{array}{c}3383- \\
3256\end{array}$ & $\begin{array}{c}3370- \\
3350\end{array}$ & $\begin{array}{c}3395- \\
3256\end{array}$ & $\begin{array}{c}-\mathrm{OH} \\
\text { carboxyl }\end{array}$ & [37] \\
\hline 2923 & 2930 & 2936 & $\mathrm{C}-\mathrm{H}$ alkane & [37] \\
\hline 1740 & $\begin{array}{c}1748- \\
1732\end{array}$ & $\begin{array}{c}1742- \\
1734\end{array}$ & RCOOR & {$[22,23]$} \\
\hline $\begin{array}{c}1625- \\
1604\end{array}$ & 1636 & 1628 & $\begin{array}{c}\mathrm{C}=\mathrm{O} \\
\text { carbonyl }\end{array}$ & $\begin{array}{c}{[22,23} \\
37]\end{array}$ \\
\hline 1098 & $\begin{array}{c}1098- \\
1101\end{array}$ & 1098 & $\begin{array}{c}\mathrm{C}-\mathrm{O} \\
\text { stretch }\end{array}$ & $\begin{array}{c}{[22,23} \\
37]\end{array}$ \\
\hline
\end{tabular}

\section{Conclusion}

Dragon fruit peels contain pectin, which can be extracted with $\mathrm{HCl}$ solution and yield an $11 \%$ pectin. Extracted pectin can be used for bioplastic synthesis mixed with ethylene glycol plasticizer. The moisture content of pectin bioplastic of dragon fruit peels is 5.71$12 \%$, while the pectin and ethylene glycol of dragon fruit peels is $2.86-5.71 \%$. FT-IR spectra showed that bioplastics belong to the pectin group, which is indicated by carbonyl absorption in $1636-1628 \mathrm{~cm}^{-1}$ and the C-O stretching group at $1098-1101 \mathrm{~cm}^{-1}$.

\section{Acknowledgment}

The author would like to thank the Institute of Research and Community Service (LPPM) Universitas Sanata Dharma for providing the research grant.

\section{References}

[1] Chien-Chung Chen, Ju-Yu Chueh, How Tseng, HawMing Huang and Sheng-Yang Lee, Preparation and characterization of biodegradable PLA polymeric blends, Biomaterials, 24, 7, (2003), 1167-1173 https://doi.org/10.1016/S0142-9612(02)00466-0

[2] José A. Heredia-Guerrero, José J. Benítez, Pietro Cataldi, Uttam C. Paul, Marco Contardi, Roberto Cingolani, Ilker S. Bayer, Antonio Heredia and Athanassia Athanassiou, All-Natural Sustainable Packaging Materials Inspired by Plant Cuticles, Advanced Sustainable Systems, 1, 1-2, (2017), 1600024 https://doi.org/10.1002/adsu.201600024

[3] A. K. Mohanty, M. Misra and G. Hinrichsen, Biofibres, biodegradable polymers and biocomposites: An overview, Macromolecular Materials and Engineering, 276, (2000), 1-24 https://doi.org/10.1002/(SICI)1439-

2054(20000301)276:1<1::AID-MAME1>3.0.CO;2-W
[4] Rafat Siddique, Jamal Khatib and Inderpreet Kaur, Use of recycled plastic in concrete: a review, Waste Management, 28, 10, (2008), 1835-1852 https://doi.org/10.1016/j.wasman.2007.09.011

[5] Cecilia Cecchini, Bioplastics made from upcycled food waste. Prospects for their use in the field of design, The Design Journal, 20, sup1, (2017), S1596S1610

https://doi.org/10.1080/14606925.2017.1352684

[6] Maja Rujnić-Sokele and Ana Pilipović, Challenges and opportunities of biodegradable plastics: A mini review, Waste Management \& Research, 35, 2, (2017), 132-140 https://doi.org/10.1177/0734242X16683272

[7] Korawit Chaisu, Bioplastic Industry from Agricultural Waste in Thailand, Journal of Advanced Agricultural Technologies, 3, 4, (2016), 310-313 https://doi.org/10.18178/joaat.3.4.310-313

[8] Tanja Narancic, Steven Verstichel, Srinivasa Reddy Chaganti, Laura Morales-Gamez, Shane T. Kenny, Bruno De Wilde, Ramesh Babu Padamati and Kevin E. O'Connor, Biodegradable Plastic Blends Create New Possibilities for End-of-Life Management of Plastics but They Are Not a Panacea for Plastic Pollution, Environmental Science \& Technology, 52, 18, (2018), 10441-10452 https://doi.org/10.1021/acs.est.8b02963

[9] Dion Bisara, Indonesia Second Largest Food Waster in: Jakarta Globe, Jakarta Globe, Jakarta, 2017,

[10] Yiu Fai Tsang, Vanish Kumar, Pallabi Samadar, Yi Yang, Jechan Lee, Yong Sik Ok, Hocheol Song, KiHyun Kim, Eilhann E. Kwon and Young Jae Jeon, Production of bioplastic through food waste valorization, Environment International, 127, (2019), 625-644 https://doi.org/10.1016/j.envint.2019.03.076

[11] Veronika Bátori, Mostafa Jabbari, Dan Åkesson, Patrik R. Lennartsson, Mohammad J. Taherzadeh and Akram Zamani, Production of Pectin-Cellulose Biofilms: A New Approach for Citrus Waste Recycling, International Journal of Polymer Science, 2017, Article ID 9732329, (2017), 1-9 https://doi.org/10.1155/2017/9732329

[12] Veronika Batori, Magnus Lundin, Dan Akesson, Patrik R. Lennartsson, Mohammad J. Taherzadeh and Akram Zamani, The Effect of Glycerol, Sugar, and Maleic Anhydride on Pectin-Cellulose Thin Films Prepared from Orange Waste, Polymers, 11, 3, (2019), 392 https://doi.org/10.3390/polym11030392

[13] Jesper Gustafsson, Mikael Landberg, Veronika Bátori, Dan Akesson, Mohammad J. Taherzadeh and Akram Zamani, Development of Bio-Based Films and 3D Objects from Apple Pomace, Polymers, 11, 2, (2019), 289 https://doi.org/10.3390/polym11020289

[14] Dayang Norulfairuz Abang Zaidel, Nurul Aqilah Makhtar, Yanti Maslina Mohd. Jusoh and Ida Idayu Muhamad, Efficiency and thermal stability of encapsulated anthocyanins from red dragon fruit (Hylocereus Polyrhizus) using microwave-assisted technique, Chemical Engineering Transactions, 43, (2015), 127-132 https://doi.org/10.3303/CET1543022

[15] Dayang Norulfairuz Abang Zaidel, Jamaeyah Md. Rashid, Nurul Hazirah Hamidon, Liza Md. Salleh and Angzzas Sari Mohd. Kassim, Extraction and Characterisation of Pectin from Dragon Fruit (Hylocereus Polyrhizus) Peels, Chemical Engineering 
Transactions, 56, (2017), 805-810

https://doi.org/10.3303/CET1756135

[16] Erza Bestari Pranutik Agne, Rum Hastuti and Khabibi, Ekstraksi dan Uji Kestabilan Zat Warna Betasianin dari Kulit Buah Naga (Hylocereus polyrhizus) serta Aplikasinya sebagai Pewarna Alami Pangan, Jurnal Kimia Sains dan Aplikasi 13, 2, (2010), 51-56 https://doi.org/10.14710/jksa.13.2.51-56

[17] Yelfira Sari, Adlis Santoni and Elisabet Elisabet, Comparative Test of Color Stability between Betalain Pigments of Red Dragon Fruits and Anthocyanin Pigments from Tamarillo Fruit at Various pH, Jurnal Kimia Sains dan Aplikasi, 21, 3, (2018), 107-112 https://doi.org/10.14710/jksa.21.3.107-112

[18] Bantolo, Berkah Petani Buah Naga Banyuwangi di Tengah Pandemi Covid 19, in: Agrofarm Informasi Agribisnis, Agrofarm.co.id, Jakarta, 2020,

[19]Arantzazu Valdés, Nuria Burgos, Alfonso Jiménez and María Garrigós, Natural Pectin Polysaccharides as Edible Coatings, Coatings, 5, 4, (2015), 865-886 https://doi.org/10.3390/coatings5040865

[20]M. Ragab, M. F. Osman, M. E. Khalil and M. S. Gouda, Banana (Musa sp.) peels as a source of pectin and some food nutrients, Journal of Sustainable Agricultural Sciences, 42, 4, (2016), 88-102 https://dx.doi.org/10.21608/jsas.2016.3028

[21] B. Jamilah, C. E. Shu, M. Kharidah, M. A. Dzulkifly and A. Noranizan, Physico-chemical Characteristic of Red Pitaya (Hylocereus polyrhizus) peel, International Food Research Journal 18, (2011), 278286

[22]Megawati and Adientya Yaniz Ulinuha, Ekstraksi Pektin Kulit Buah Naga (Dragon Fruit) dan Aplikasinya Sebagai Edible Film, Jurnal Bahan Alam Terbarukan, 4, 1, (2015), 16-23

[23]Narazelina Sah Mohd. Ismail, Nazaruddin Ramli, Norziah Mohd. Hani and Zainudin Meon, Extraction and Characterization of Pectin from Dragon Fruit (Hylocereus polyrhizus) using Various Extraction Conditions, Sains Malaysiana 41, 1, (2012), 41-45

[24]Shahrooz Rahmati, Aminah Abdullah and Oon Lee Kang, Effects of different microwave intensity on the extraction yield and physicochemical properties of pectin from dragon fruit (Hylocereus polyrhizus) peels, Bioactive Carbohydrates and Dietary Fibre, 18, (2019), 100186

https://doi.org/10.1016/j.bcdf.2019.100186

[25]Cristina Mellinas, Marina Ramos, Alfonso Jimenez and María Carmen Garrigós, Recent Trends in the Use of Pectin from Agro-Waste Residues as a Natural-Based Biopolymer for Food Packaging Applications, Materials, 13, 3, (2020), 673 https://doi.org/10.3390/ma13030673

[26]P. H. Yu, H. Chua, A. L. Huang, W. Lo and G. Q. Chen, Conversion of Food Industrial Wastes into Bioplastics, Applied Biochemistry and Biotechnology, 70, (1998), 603-614

https://doi.org/10.1007/BF02920172

[27]Colin D. May, Industrial Pectins: Sources, Production and Applications, Carbohydrate Polymers, 12, 1, (1990), 79-99 https://doi.org/10.1016/0144-8617(90)90105-2

[28]Abubakar Tuhuloula, Lestari Budiyarti and Etha Nur Fitriana, Karakterisasi Pektin Dengan
Memanfaatkan Limbah Kulit Pisang Menggunakan Metode Ekstraksi, Konversi, 2, 1, (2013), 21-27 http://dx.doi.org/10.20527/k.v2i1.123

[29]Nurhayati Nurhayati, Maryanto Maryanto and Rika Tafrikhah, Ekstraksi Pektin dari Kulit dan Tandan Pisang dengan Variasi Suhu dan Metode (Pectin Extraction from Banana Peels and Bunch with Various Temperatures and Methods), agriTECH, 36, 3, (2016), 327 https://doi.org/10.22146/agritech.16605

[30]Giovanni Perotto, Luca Ceseracciu, Roberto Simonutti, Uttam C. Paul, Susana Guzman-Puyol, Thi-Nga Tran, Ilker S. Bayer and Athanassia Athanassiou, Bioplastics from vegetable waste via an eco-friendly water-based process, Green Chemistry, 20, 4, (2018), 894-902 https://doi.org/10.1039/C7GC03368K

[31] Phaviphu Khamsucharit, Kamlai Laohaphatanalert, Paiboolya Gavinlertvatana, Klanarong Sriroth and Kunruedee Sangseethong, Characterization of pectin extracted from banana peels of different varieties, Food Science and Biotechnology, 27, 3, (2018), 623-629 https://doi.org/10.1007/s10068-017-0302-0

[32]Melissa B. Agustin, Bashir Ahmmad, Shanna Marie M. Alonzo and Famille M. Patriana, Bioplastic based on starch and cellulose nanocrystals from rice straw, Journal of Reinforced Plastics and Composites, 33, 24, (2014), 2205-2213 https://doi.org/10.1177\%2F0731684414558325

[33] Suman Gujar, Bartik Pandel and A. S. Jethoo, Effect of Plasticizer on Mechanical and Moisture Absorption Properties of Eco-friendly Corn Starchbased Bioplastic, Nature Environment and Pollution Technology, 13, 2, (2014), 425 - 428

[34]M. I. J. Ibrahim, S. M. Sapuan, E. S. Zainudin and M. Y. M. Zuhri, Physical, thermal, morphological, and tensile properties of cornstarch-based films as affected by different plasticizers, International Journal of Food Properties, 22, 1, (2019), 925-941 https://doi.org/10.1080/10942912.2019.1618324

[35]M. H. S. Ginting, R. Hasibuan, M. Lubis, F. Alanjani, F. A. Winoto and R. C. Siregar, Utilization of Avocado Seeds as Bioplastic Films Filler Chitosan and Ethylene Glycol Plasticizer, Asian Journal of Chemistry, 30, 7, (2018), 1569-1573 https://doi.org/10.14233/ajchem.2018.21254

[36]Alexander Jones, Mark Ashton Zeller and Suraj Sharma, Thermal, mechanical, and moisture absorption properties of egg white protein bioplastics with natural rubber and glycerol, Progress in Biomaterials, 2, 12, (2013), 1-13 https://doi.org/10.1186/2194-0517-2-12

[37] Aya Sofia, Agung Tri Prasetya and Ella Kusumastuti, Komparasi Bioplastik Kulit Labu Kuning-Kitosan dengan Plasticizer dari Berbagai Variasi Sumber Gliserol, Indonesian Journal of Chemical Science, 6, 2, (2017), 110-116

[38]Meilina Rahayu Utami, Latifah and Nuni Widiarti, Sintesis Plastik Biodegradable dari Kulit Pisang dengan Penambahan Kitosan dan Plasticizer Gliserol, Indonesian Journal of Chemical Science, 3, 2, (2014), 163-167

[39]Yuana Elly Agustin and Karsono Samuel Padmawijaya, Sintesis Bioplastik dari Kitosan-Pati 
Kulit Pisang Kepok dengan Penambahan Zat Adiktif, Jurnal Teknik Kimia, 10, 2, (2016), 40-48

[40] Eldo Sularto Marbun, Sintesis Bioplastik dari Pati Ubi Jalar Menggunakan Penguat Logam ZnO dan Penguat Alami Selulosa, undergraduate thesis, Program Studi Teknik Kimia, Universitas Indonesia 